\title{
LECTINS FROM Pisum arvense SEEDS BEHAVE DIFFERENTLY FROM STORAGE PROTEINS DURING GERMINATION IN THE DARKNESS ${ }^{1}$
}

\author{
LUIZA IZABEL M. MOREIRA DA SILVA ${ }^{2}$, MÁRCIO VIANA RAMOS ${ }^{3}$, JOÃO \\ BATISTA CAJAZEIRAS ${ }^{4}$, PATRÍCIA RODRIGUES FERREIRA ${ }^{4}$, CARLOS ALBERTO \\ V. CARVALHO ${ }^{4}$, THALLES BARBOSA GRANGEIRO ${ }^{5}$, EDSON PAULA NUNES ${ }^{6}$, \\ ALEXANDRE HOLANDA SAMPAIO ${ }^{7}$, BEATRIZ TUPINAMBÁ FREITAS ${ }^{8}$, JOAQUIM \\ ALBENÍSIO G. DA SILVEIRA ${ }^{9}$ AND BENILDO SOUSA CAVADA $* *$
}

BioMoL-Lab, Universidade Federal do Ceará, Fortaleza-Ceará, Brasil

\begin{abstract}
The mobilization of seed proteins from Pisum arvense L. during germination in the absence of light was studied. The seeds were found to be completely consumed 22 days after germination and seedlings ceased growth after the $18^{\text {th }}$ day. SDS-PAGE indicated that the main protein bands correspond to high molecular mass storage proteins which undergo proteolysis in the initial stages of germination and are not detected after the $7^{\text {th }}$ day of germination. However, the corresponding lectin profiles were detected during the entire germination process, suggesting that these proteins are strongly resistant to seed proteolytic enzymes and should be important for seedling establishment. Furthermore, haemagglutinating activity in cotyledons was detected until 22 days after germination, indicating that the lectins remain active even in senescent cotyledons.
\end{abstract}

ADDITIONAL INDEX TERMS: Lectin, protein mobilization, seed germination.

\section{LECTINAS DE SEMENTES DE Pisum arvense COMPORTAM-SE DIFERENTEMENTE DAS PROTEINAS DE RESERVA DURANTE A GERMINAÇÃO NO ESCURO}

RESUMO - A mobilização das proteínas de sementes de Pisum arvense L. durante a germinação na ausência de luz foi estudada. As sementes foram completamente exauridas de suas reservas após 22 dias

Recebido: 24/5/1999 - Aceito: 19/08/2000

1. Parte da Tese apresentada pelo primeiro autor à Universidade Federal do Ceará - UFC, para obtenção do título de Doutor em Bioquímica Vegetal.

2. Professor Adjunto, Doutor. Departamento de Farmácia, UFC.

3. Professor Visitante, Doutor. Departamento de Biologia, UFC.

4. Estudante de Mestrado, Departamento de Bioquímica e Biologia Molecular, UFC.

5. Professor Adjunto, Doutor. Bolsista do CNPq. Departamento de Biologia, UFC.

6. Professor Adjunto, Mestre. Departamento de Biologia, UFC.

7. Professor Adjunto, PhD. Bolsista do CNPq. Departamento de Engenharia de Pesca, UFC.

8. MSc. em Bioquímica. Departamento de Bioquímica e Biologia Molecular, UFC.

9. Professor Adjunto, Doutor. Bolsista do CNPq. Departamento de Bioquímica e Biologia Molecular da UFC.

*Corresponding author: BioMoL-Lab, Universidade Federal do Ceará, Campus do Pici, Caixa Postal 6033, Fortaleza-Ceará, Brasil. CEP 60.451-970. E-mail: bscavada@ufc.br. 
de germinação e as plântulas cresceram até o $18^{\circ}$ dia de germinação. Experimentos de eletroforese em gel de poliacrilamida em presença de SDS indicaram que as principais bandas protéicas, correspondendo às proteínas de reserva de alta massa molecular, foram detectadas apenas até o $7^{\circ}$ dia após a germinação. Entretanto, as bandas protéicas correspondentes às lectinas da semente puderam ser detectadas ao longo de todo o processo germinativo, sugerindo que essas proteínas são fortemente resistentes à ação das proteases da semente e devem, de alguma forma, ser importantes para o estabelecimento das plântulas. A atividade hemaglutinante nos cotilédones foi detectada até o $22^{\circ}$ dia de germinação, indicando que as lectinas também permaneceram ativas quando os cotilédones estavam bastante exauridos de suas reservas.

TERMOS ADICIONAIS PARA INDEXAÇÃO: Germinação de sementes, mobilização de proteínas, lectina.

\section{INTRODUCTION}

Lectins are proteins widely distributed in nature, forming a highly heterogeneous group of carbohydrate-binding proteins (Loris et al., 1998). In plants, they have been detected and isolated from a large number of taxonomic groups, the leguminous seeds being the most exploited in respect to their structural characterization and biological applications (Van Damme et al., 1998). Despite the impressive studies with seed lectins, the physiological role of these proteins remains controversial. This is mainly due to: (1) the ability of these proteins to specifically discriminate complex carbohydrates naturally occurring in cell surface glycoconjugates; (2) the display of unrelated effects in many biological systems and (3) their occurrence and sub-cellular localization in plants (Pére andRougé, 1982; Causse andRougé, 1983; Toda et al., 1998; Trombetta andHelenius, 1998). Over a long period many hypotheses related to their functions in nature have been raised (Cavada et al., 1993; Ramos, 1997).

In the earlier studies on their sub-cellular localization, it was established that lectins from legume seeds were generally accumulated in protein bodies (Etzler, 1986; Wenzel andRudiger, 1995). Based on this information, it has been suggested that these proteins should be seed storage proteins involved in amino acid supply during seed germination and seedling growth. However, studies carried out by Moreira andCavada (1984), Cavada et al. (1990) and Cavada et al. (1994) are not in agreement with this hypothesis, based upon seed germination studies that have compared the mobilization of storage proteins and the behaviour of the lectins during the germination process. In the present report we advance the idea that, although accumulated in protein bodies, the legume lectins have a different behavior from classical high molecular mass storage proteins and that the lectins should play a more relevant role in seedling establishment.

\section{MATERIAL AND METHODS}

Plant material. Pisum arvense L. Seeds were harvested from plants growing at Uruguaiana, Rio Grande do Sul, Brazil. After collecting, the seeds were stored at $4{ }^{\circ} \mathrm{C}$ until use.

Germination in the darkness. Healthy seeds ranging from $0.17 \mathrm{~g}$ up to $0.21 \mathrm{~g}$ were carefully selected to be used in germination in the dark. Seeds were initially washed with distilled water and placed between two sheets of filter paper $3 \mathrm{M}$ moistened with distilled water, rolled-up and kept in a water saturated cube, in the dark. The quiescent seeds were taken as day zero. Germinating seeds and seedlings were collected from 1, 4, 7, 10, 13, 16, 19 and 22 days after imbibition. Cotyledons and axes were carefully separated, lyophilized, powdered and stored for further determinations (soluble protein content, haemagglutinating activity and electrophoresis). Two representative cotyledons and axes were taken from each sample to determine fresh and dry matter. 
Protein content. The powder prepared from quiescent seeds and germinated cotyledons and axes were suspended $(1: 10 \mathrm{~m} / \mathrm{v})$ in $0,15 \mathrm{~mol} / \mathrm{L}^{-1}$ $\mathrm{NaCl}$, the mixture allowed to agitate for $3 \mathrm{~h}$ at 25 ${ }^{\circ} \mathrm{C}$ and then centrifuged at $16,000 \mathrm{x}$ g for $20 \mathrm{~min}$ at $4{ }^{\circ} \mathrm{C}$. The supernatants obtained were used for determination of soluble protein content and haemagglutinating activity. Protein concentrations were estimated by the Bradford assay (Bradford, 1976) using bovine serum albumin (BSA) as standard.

Haemagglutinating activity. The haemagglutinating activity was determined in all crude extracts from cotyledons and axes using a $2 \%$ suspension of rabbit red blood cells by a standard procedure as described in Ramos et al. (1996). The extracts were submitted to serial two-fold dilutions in small glass tubes and mixed $(1: 1)$ with the blood suspension. The extent of haemagglutination was monitored visually after the tubes had been left to stand at $37{ }^{\circ} \mathrm{C}$ for $30 \mathrm{~min}$ and at room temperature for an additional $30 \mathrm{~min}$. The results are reported as haemagglutination titer $(\mathrm{HU} / \mathrm{ml})$ which is the reciprocal of the highest dilution still giving a visible agglutination.

\section{Sodium Dodecyl Sulphate-Polyacrylamide Gel} Electrophoresis (SDS-PAGE). Protein mobilization during germination and seedling growth was studied by SDS-PAGE adapted from Laemmli (1970) and carried out in a $2 \mathrm{~mm}$ thick vertical slab gel (12.5\% acrylamide). Cotyledons and axes $\left(5 \mathrm{~g} / \mathrm{L}^{-1}\right)$ from zero to 22 days of germination were incubated in $62.5 \mathrm{mM}$ Tris$\mathrm{HCl}$ buffer, $\mathrm{pH} 6.8$, containing $10 \%$ SDS at 100 ${ }^{\circ} \mathrm{C}$ for $5 \mathrm{~min}$. After incubation the insoluble material was removed by centrifugation at $15,000 \mathrm{x} \mathrm{g}$ for $10 \mathrm{~min}$ at $5{ }^{\circ} \mathrm{C}$. The supernatants $(40 \mu \mathrm{L})$ were applied onto the gel and the electrophoresis was carried out at constant current $(50 \mathrm{~mA})$ for $3 \mathrm{~h}$. The protein bands were visualized by staining with Coomassie Brilliant Blue R-250.

\section{RESULTS AND DISCUSSION}

Experiments to evaluate lectins and the other seed proteins in order to speculate about their functions in seed germination are not scarce in the literature (Causse andRougé, 1983; Cavada et al., 1990; Cavada et al., 1994; Oliveira et al., 1998). This strategy seems to be common, although limited in itself, since lectins are judged as ordinary proteins. However, results from immunochemical and electrophoretic studies are useful to compare the lectin and seed storage proteins in some aspects. Therefore, we used the experience and the results of our previous studies, with the seed lectins from Canavalia brasiliensis (Cavada et al., 1990) and Dioclea guianensis, subtribe Diocleinae (Cavada et al.,1994) to investigate the mobilization of the lectin from Pisum arvense during germination.

Pisum arvense, like many other leguminous species, expresses in its seeds a lectin which agglutinates red blood cells and exhibits potential applications (Silva, 1997). Despite the biochemical and structural features of this lectin, and its ability to interact specifically with complex carbohydrates, an endogenous receptor for the lectin has not been identified yet. Thus, one question which remains to be solved is why a protein with many peculiar characteristics is expressed in the seeds and why it occurs usually in large amounts. Certainly, further work on lectin physiology would undoubtedly contribute significantly to answer these questions.

Seeds of Pisum arvense when germinated in the dark produced healthy seedlings and the cotyledons were completely exhausted after 22 days of germination in the dark. We have followed the mobilization of the seed proteins by determining fresh and dry matter, protein content, and lectin haemagglutinating activity in cotyledons and axes. In addition, protein profiles were also examined by SDS-PAGE in order to compare the behaviour of the lectins with other storage proteins.

During germination, cotyledons apparently retained their fresh matter while axes fresh matter increased to a maximum at the $13^{\text {th }}$ day (Figure 1). The dry matter in cotyledons 

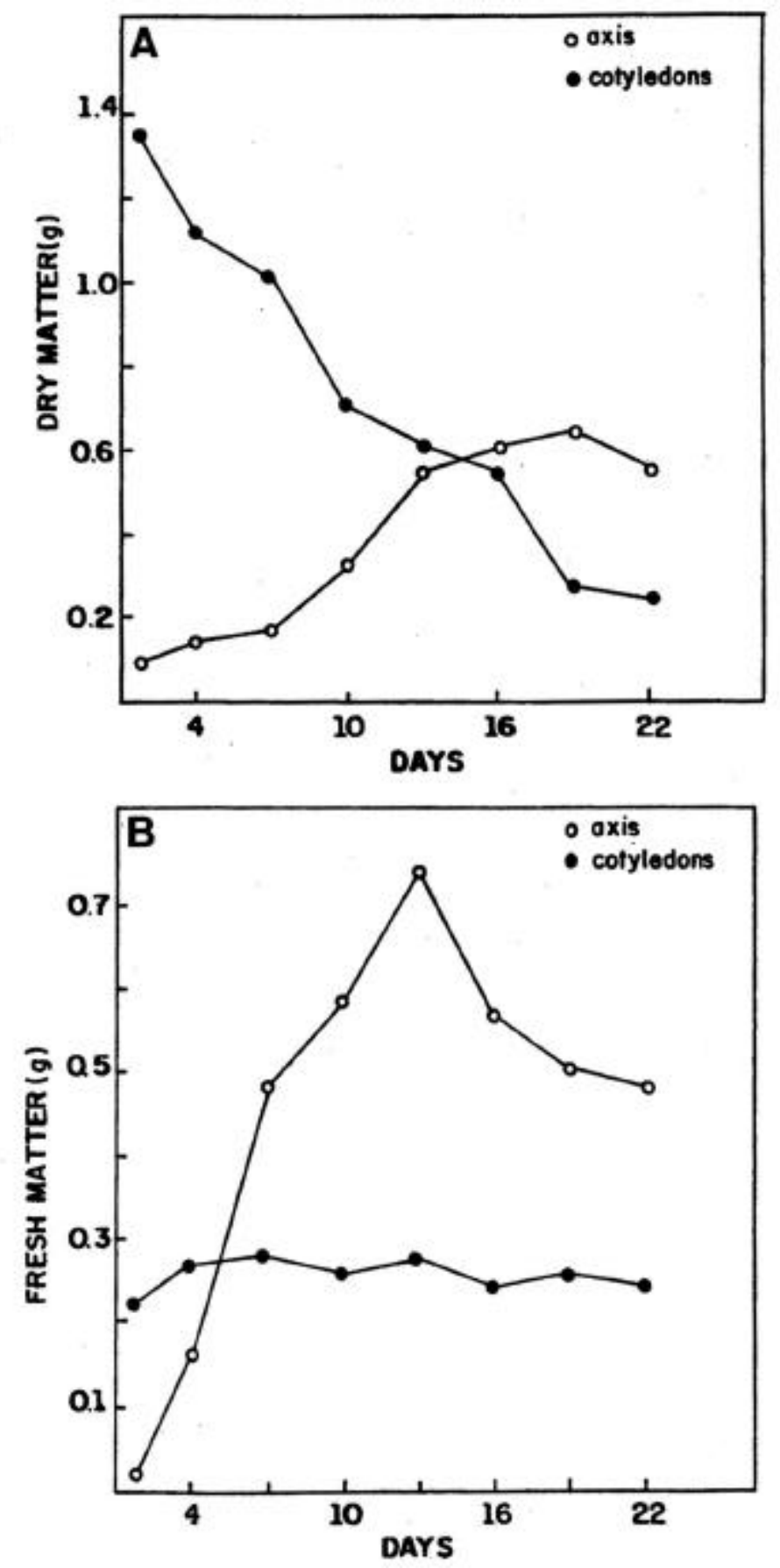

FIGURE 1 - Dry (A) and fresh (B) matter if cittkedibs (•) and (o) from Pisum arvense seedlings during germination in the dark. 
reached the minimum at $22^{\text {nd }}$ day, while axes dry matter increased until the $19^{\text {th }}$ day after germination (Figure 1). It should be noted that in the absence of light, seedlings could not maintain their growth rate after the cotyledons were exhausted. As shown in Figure 2, the protein content in cotyledons decreased after the $4^{\text {th }}$ day of germination. This is in agreement with the electrophoretic patterns presented in Figure 3 which shows that high molecular mass proteins begin to disappear on the $4^{\text {th }}$ day. Also, by this stage, the axes exhibited maximum growth rate. Probably, the amino acids supplied by the storage proteins, mobilized from cotyledons, were partly responsible for the increase in the growth during the early stages of seedling development.

The haemagglutinating lectin activity was also examined in order to compare its presence with the protein mobilization. The lectin activity shows behavior similar to that of the protein content (Figure 2). Nevertheless, when its specific activity is considered, it becomes clear that lectins remain in cotyledons while storage proteins are mobilized. This is evident at the $19^{\text {th }}$ day after germination. At this time the total protein content in cotyledons decreased while specific lectin activity increased. After the $13^{\text {th }}$ day of germination, when the major proteins were completely broken down into smaller peptides, as evidenced by SDS-PAGE, the specific lectin activity increased substantially. These results support the hypothesis that, although cotyledons are almost consumed, lectins are the main proteins preserved until cotyledons are drained. These findings were further confirmed by gel electrophoresis (Figure 3). The high molecular mass protein bands disappeared after the $7^{\text {th }}$ day of germination while the lectin bands were present until the $22^{\text {nd }}$ day.

According to these findings, as well as previously reported results on legume lectin behaviour during seed germination (Cavada et al., 1990; Moreira et al., 1993; Oliveira et al., 1998), seed lectins in legume plants may play some other role than storage proteins. In fact, this latter statement came from the observation that many lectins in seeds are located in the protein bodies, a typical plant cell sub-cellular compartment where storage proteins are deposited (Etzler, 1986). In spite of the differential behaviour of the lectins compared to the main high molecular mass proteins, it is suggested that these proteins may remain in cotyledons to protect them from pathogen or predator attack (Cavada et al., 1993). Many reports refer to legume and non legume seed lectins as defense proteins involved in the recognition and interaction with prokaryotic and eukaryotic organisms such as phytopathogenic bacteria and fungi (Ayuba et al., 1991; Ayuba et al., 1992; Ayuba et al., 1994). These findings were based mainly on the properties of the carbohydrate-binding site of the lectins (Bourne et al., 1994). Furthermore, according to our studies, legume lectins seem to be more involved in an elaborate plant defense system than in ordinary storage functions. This idea has been supported by the fact that we have successfully demonstrated that many other purified seed legume lectins in biological assays show insecticidal properties (Grangeiro et al., 1998a, Grangeiro et al., 1998b). Thus the presence of lectins in protein bodies may be considered as a plant strategy to accumulate large amounts of these proteins in a way that they protect storage proteins which, in turn, represent the most important source of amino acids for plant growth in the earlier stages of development, even when seeds germinate in the presence of light. In fact, the lectins present in Canavalia brasiliensis seeds were also preserved from proteolytic processing during germination in presence of light, differing from the classical storage proteins (Cavada et al., 1990). Recently, a galactose-specific lectin from seeds of the leguminous plant, Luetezelburgia auriculata was shown to possess an anti-fungal activity against Fusarium solani and this activity was promptly inhibited by the presence of galactose in the reaction medium (Melo et al., 1998). Although conclusive results are not yet available in this matter, the understanding of the role of plant lectins advances. 


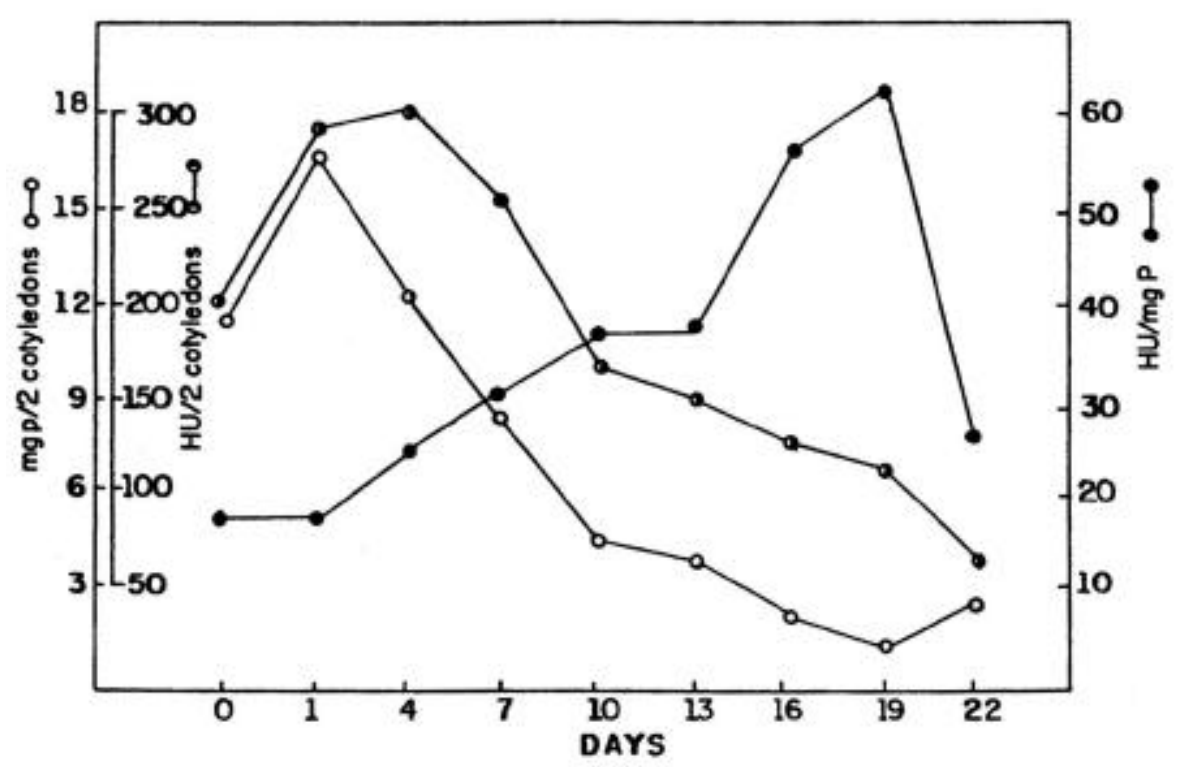

FIGURE 2 - Protein content (o), haemagglutinating activity (•) and lectin specific activity $(\bullet)$ of cotyledons from Pisum arvense during germination in the dark.

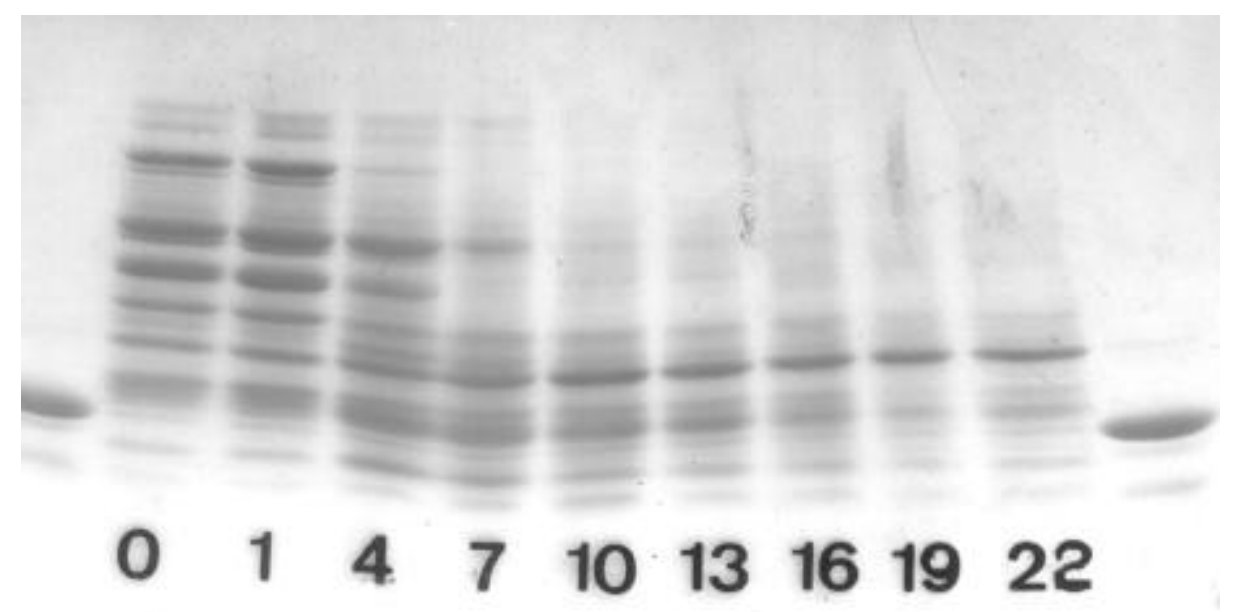

FIGURE 3 - SDS-PAGE of total proteins from Pisum arvense cotyledons at various stages of germination and seedling growth in the dark. The protein profiles of cotyledons taken from 0, 1-, 4-, 7-, 10-, 13-, 16-, 19- and 22-day-old seedlings are shown, as indicated. The purified lectin from $P$. arvense (first and last lanes) was included for comparison. 


\section{ACKNOWLEDGEMENTS}

This work was supported by grants from CNPq, CAPES, FUNCAP, PADCT, IFS, BNB and BioTools Ecological Foundation.

\section{REFERENCES}

AYUBA, A.; CHATELAIN, C. \& ROUGÉ, P. Legume lectins interact with muramic and $\mathrm{N}$ acetylmuramic acid. FEBS Letters, 289:102104, 1991.

AYUBA, A.; MARTIN, D. \& ROUGÉ, P. Recognition of muramic acid and $\mathrm{N}$ acetylmuramic acid by Leguminosae lectins: possible role in plant-bacteria interactions. FEMS Microbiology Letters, 92:41-46, 1992.

AYUBA, A.; CAUSSE, H.; VAN DAMME, E.J.M.; PEUMANS, W.J.; BOURNE, Y.; CAMBILLAU, C. \& ROUGÉ, P. Interactions of plant lectins with the components of the bacterial cell wall peptidoglycan. Biochemical Systematics and Ecology, 22:153-159, 1994.

BOURNE, Y.; AYUBA, A.; ROUGÉ, P. \& CAMBILLAU, C. Interaction of a legume lectin with two components of the bacterial cell wall. Journal of Biological Chemistry, 269(13):9429-9435, 1994.

BRADFORD, M.M., A rapid and sensitive method for the quantification of micrograms quantities of proteins - dye - binding. Analytical Biochemistry, 72:248-254, 1976.

CAUSSE, H. \& ROUGÉ, P. Lectin release from imbibed soybean seed and its possible function. In: BOG-HANSEN, T.C. (Ed.) Lectins: Biology, Biochemistry, Clinical Biochemistry. Berlin, Walter De Gruyter, 1983. v.3, p.559-572.
CAVADA, B.S., CRISÓSTOMO, C.V., SILVA, L.M.A., OLIVEIRA, J.T.A. \& MOREIRA, R.A. Comportamento da lectina de sementes de Canavalia brasiliensis Mart. durante a germinação em presença de luz. Acta Botanica Brasilica, 4:13-20, 1990.

CAVADA, B.S.; MOREIRA, R.A.; OLIVEIRA, J.T.A. \& GRANGEIRO, T.B. Primary structures and functions of plant lectins. Revista Brasileira de Fisiologia Vegetal, 5:193-201, 1993.

CAVADA, B.S., GRANGEIRO, T.B., RAMOS, M.V., CRISÓSTOMO, C.V., SILVA, L.M.A., MOREIRA, R.A. \& OLIVEIRA, J.T.A. Lectin from Dioclea guianensis var. lasiophylla Duke seeds mobilization during germination and seedling growth in the dark. Revista Brasileira de Fisiologia Vegetal, 6:21-25, 1994.

ETZLER, M.E. Distribution and function of plant lectins. In: LIENER, I.E.; SHARON, N. \& GOLDSTEIN, I.J. (Eds.) The lectins: Properties, Functions, and Applications in Biology and Medicine. New York, Academic Press, 1986. 600 p.

GRANGEIRO, T.B.; SALES, F.J.M.; RAMOS, M.V. \& CAVADA, B.S. Efeito de lectinas vegetais sobre o crescimento e desenvolvimento de insetos. Uma revisão. In: SALES, F.J.M. (Ed.) Leitura Entomológica. Itaiçaba, Ceará, Biotools Ecological Foundation, 1998a. v.1, p.125-186.

GRANGEIRO, T.B.; FREIRE-FILHO, F.R.; CAJAZEIRAS, J.B.; RAMOS, M.V. \& CAVADA, B.S. Lectinas de Leguminosas da sub-tribo Diocleinae: proteínas com atividades inseticida e probiótica. In: SALES, F.J.M. (Ed.). Leitura Entomológica. Itaiçaba, Ceará, Biotools Ecological Foundation, 1998b. v.1, p.207-246. 
LAEMMLI, U.K. Cleavage of structural protein during the assembly of the head of bacteriophage T4. Nature, 227:680-685, 1970.

LORIS, R.; HAMELRYCK, T.; BOUCKAERT, J. \& WYNS, L. Legume lectin structure. Biochimica et Biophysica Acta, 1383:9-36, 1998.

MELO, V.M.M.; VASCONCELOS, I.M. \& OLIVEIRA, J.T.A. Atividade anti-fúngica da lectina da leguminosa Luetezelburgia auriculata (FR. ALL.) Ducke. In: CONGRESSO NACIONAL DE BOTÂNICA, 49, Salvador, 1998. Resumos. Salvador, SBB/UFBA, 1998. p.244.

MOREIRA, R.A. \& CAVADA, B.S. Lectin from Canavalia brasiliensis (Mart.). Isolation, characterisation and behaviour during germination. Biologia Plantarum, 26:113-120, 1984.

MOREIRA, R.A., SILVA, L.M.A., HORTA, A.C.G., OLIVEIRA, J.T.A \& CAVADA, B.S. Lectin from Canavalia brasiliensis Mart. Behaviour during maturation and detection of a lectin precursor. Revista Brasileira de Fisiologia Vegetal, 5:133-138, 1993.

OLIVEIRA, J.T.A., MORAES, S.D.M., CAVADA, B.S., MOREIRA, R.A. \& VASCONCELOS, I.M. Protein and lectin immobilization during Erythrina velutina forma aurantiaca seed germination and seedling growth in the dark. Revista Brasileira de Fisiologia Vegetal, 10:25-30, 1998.

PÉRE, D. \& ROUGÉ, P. Occurrence of lectin during the life cycle of Lathyrus species. In: BOG-HANSEN, T.C. (Ed.) Lectins: Biology, Biochemistry, Clinical Biochemistry. Berlin, Walter De Gruyter, 1982. v.2, p.137-150.
RAMOS, M.V.; MOREIRA, R.A.; CAVADA, B.S.; OLIVEIRA, J.T.A. \& ROUGÉ, P. Interaction of Diocleinae lectins with specific ligants. Revista Brasileira de Fisiologia Vegetal, 8:193-199, 1996.

RAMOS, M.V. Biosynthesis and structural lectin features of the Phaseoleae, Diocleinae and the Vicieae (Leguminosae $=$ Fabaceae) under a phylogenetic perspective. Journal of Comparative Biology, 2:129-136, 1997.

SILVA, L.I.M.M. Caracterização bioquímica e estrutura primária da lectina de sementes de Pisum arvense L. Fortaleza, Universidade Federal do Ceará, 1997. 102p. Tese de Doutorado.

TODA, T.; SADI, A.M.; EGAWA, H.; ATARI, E.; QURESHI, B. \& NAGAI, Y. Affinity of four lectins for endocervical and endometrial nonneoplastic glandular epithelium. Histopathology, 32:257-263, 1998.

TROMBETTA, E.S. \& HELENIUS, A. Lectins as chaperones in glycoprotein folding. Current Opinion in Structural Biology, 8:587-592, 1998.

VAN DAMME， E.J.M.; PEUMANS， W.J.; BARRE, A. \& ROUGÉ, P. Plant lectins: a composite of several distinct families of structurally and evolutionarily related proteins with diverse biological roles. Critical Reviews in Plant Sciences, 17:575-692, 1998.

WENZEL, M. \& RUDIGER, H. Interaction of pea (Pisum sativum) lectin with pea storage proteins. Journal of Plant Physiology, 145:191-194, 1995. 